\title{
Language situation and language politics in Corsica
}

\section{[Jazyková situace a jazyková politika na Korsice]}

\author{
Jaromir Kadlec
}

DOI: 10.18355/XL.2018.11.01XL.06

\begin{abstract}
This article deals with the current language situation and language policy of the French state and Corsican self-government on the island of Corsica. The policy pursued by the French Government and the Corsican Assembly is completely contradictory. The central authorities are trying to make the language of the Republic only French, while the Corsican officials seek to make the Corsican language the second official language of the island. However, the Corsican language is on the decline, the young generation uses it less and from a long-term point of view, the language is considered to disappear.
\end{abstract}

Key words: Corsica, French, the Corsican language, language policy

\section{Anotace}

Tento článek se zabývá současnou jazykovou situací a jazykovou politikou francouzského státu a korsické samosprávy na ostrově Korsika. Politika uplatňovaná francouzskou vládou a Korsickým shromážděním je zcela protikladná. Centrální orgány se snaží, aby jazykem Republiky byla pouze francouzština, kdežto korsičtí představitelé usilují o to, aby se korsičtina stala druhým úředním jazykem ostrova. Korsičtina je však na ústupu, mladá generace ji užívá stále méně a z dlouhodobého hlediska jí hrozí zánik.

Klíčová slova: Korsika, francouzština, korsičtina, jazyková politika

\section{Zeměpisná situace}

Korsika se nachází 170 kilometrů na jihovýchod od francouzské Riviéry, 85 kilometrů na západ od Toskánka a pouhým 12 kilometrů od italského ostrova Sardinie. Se svými $8680 \mathrm{~km}^{2}$ je po Sicílii, Sardinii a Kypru čtvrtým největším ostrovem ve Středozemním moři. Dělí se na dva departementy, na Horní Korsiku (Haute-Corse) s hlavním městem Bastia a na Jižní Korsiku (Corse-du-Sud) s hlavním městem Ajaccio. Je územním společenstvím (collectivité territoriale) se zvláštním statutem majícím svůj vlastní zákonodárný (Assemblée de Corse) i výkonný (Conseil exécutif de Corse) orgán.

\section{Jazyková situace}

K 1. lednu 2013 žilo na Korsice 320200 obyvatel, 170974 v departementu Horní Korsika a 149234 v departementu Jižní Korsika. Ajaccio má 67507 obyvatel a v Bastii žije 65921 osob. Počet obyvatel na ostrově se již více než třicet let neustále zvyšuje. Od počátku šedesátých let 20 . století do dnešní doby se počet obyvatel ostrova zdvojnásobil. V letech 2008-2013 se zvýšil o 17242 , což představuje průměrný roční př́růstek $1,1 \%$. Společně s krajem Languedoc-Roussillon se jedná $\mathrm{o}$ 
největší nárůst obyvatel ze všech bývalých francouzských regionů nacházejících se v evropské části Francie. Departementy Jižní Korsika a Horní Korsika jsou v této statistice na 9. a 12. místě. Nárůst populace je způsoben výhradně migrací, nebot' počet zemřelých je na Korsice již od roku 2013 vyšší než počet zde narozených osob. V roce 2013 opustily ostrov 4 tisíce osob, ale usadilo se zde 8 tisíc nových obyvatel. $\mathrm{Na}$ Korsiku přicházejí noví osadníci zejména z bývalých regionů Provence-AlpesCôte d'Azur a Île de France. Cizinci představovali v roce 2013 přibližně $10 \%$ korsické populace, což je o něco více než je francouzský průměr, ale rozdíl se postupně snižuje, nebot' podíl cizinců se na Korsice za posledních 20 let na rozdíl od kontinentální Francie nezvýšil. Téměř všichni imigranti žijící na Korsice pocházeli z Evropy (51\%) nebo Afriky (46\%). Zajímavé je to, že v posledních letech klesá podíl Afričanů a stoupá podíl Evropanů. Nejvíce cizinců pochází stále z Maroka (33 \% v roce 2013), ale podíl Maročanů se od roku 1999 snížil o 9 \%. Z důvodu evropské integrace došlo rovněž k poklesu podílu Italů (z $19 \%$ v roce 1999 na $13 \%$ v roce 2013). Naopak výrazný nárůst byl zaznamenán u osob pocházejících z Portugalska (23\% v roce 2013 oproti $12 \%$ v roce 1999). Díky imigraci dochází také ke snižování podílu obyvatel korsického původu na ostrově. Korsičané tvoří dnes podle odhadů necelých $60 \%$ populace ostrova. Trnem v oku rodilých Korsičanů nejsou jen cizinci, ale i osoby pocházející z kontinentální Francie, které místní nazývají „pinzutu“. Řada Korsičanů žije mimo svůj ostrov, nejvíce je jich soustředěno v Marseille, kde se ke korsickému původu hlásí více než 100 tisíc obyvatel a Marseille je tak městem s nejvyšším počtem Korsičanů na světě. Další Korsičané žijí v Itálii, Spojených státech amerických a Latinské Americe.

Nejčastěji užívaným jazykem, nejvíce rozšířeným mateřským jazykem a jazykem spojujícím všechny obyvatele Korsiky je francouzština. Je mateřštinou osob pocházejících z kontinentální Francie a také mladých Korsičanů. Místním regionálním jazykem je vedle korsičtiny také bonifácština a kromě těchto jazyků se na ostrově užívají i mateřské jazyky imigranti̊, zejména arabština, portugalština a italština.

Jazykem původních obyvatel Korsiky je korsičtina, jazyk patřící společně se sardinštinou a sicilštinou do italo-románské skupiny románských jazyků. Korsičtina sice byla silně ovlivněna toskánštinou, avšak vznikla před vytvořením standardní italštiny, a proto je samostatným jazykem, který si kromě toskánštiny vypůjčil řadu lexikálních jednotek také z janovštiny a francouzštiny. Dnes má hodně blízko k moderní italštině, která vzešla z toskánštiny, a Korsičané proto mohou bez větších problémů komunikovat $\mathrm{s}$ Italy. Korsičtina není jednotná a je rozdrobená do řady dialekti̊. Velké rozdíly existují zejména mezi severem a jihem ostrova, ale mluvčí jednotlivých dialektů si přes regionální zvláštnosti korsičtiny vzájemně rozumějí. Severní dialekty mají blízko k toskánštině, jižní byly ovlivněny sardinštinou. Koršičtinou se mluví kromě Korsiky i na Sardinii, i když někteří lingvisté považují tyto varianty korsičtiny za dialekty sardinštiny. Korsičtinu ovládají pochopitelně i mnozí Korsičané žijící v kontinentální Francii, zejména v okolí Marseille.

Bonifácština se uživá ve městě Bonifacio nacházejícím se v nejjižnější části ostrova. Jedná se o variantu janovštiny, která je mnohem archaičtější než janovština užívaná v Ligurii (Dalbera, 2003: 126). Původní obyvatelé města sem přišli ve 12. a 13. století z Janova a ztratili kontakt se svou domovinou. Tento jazyk ovládá jen

XLinguae, Volume 11 Issue 1XL, January 2018, ISSN 1337-8384, eISSN 2453-711X 
velmi málo starých lidí ve městě Bonifacio a řada Korsičanů ho považuje za dialekt korsičtiny, což je zcela neopodstatněné.

$\mathrm{Z}$ důvodu neexistence úředních údajů o počtu mluvčích jednotlivých jazyků ve Francii je velmi obtížné stanovit počet osob ovládajících korsičtinu, př́ípadně bonifácštinu. Korsičtina přestala být předávána z generace na generaci a v současnosti je mateřštinou pouze velmi malé části mladých Korsičanů, nebot' rodiče vychovávají své děti ve francouzštině. Naopak starší Korsičané korsicky vesměs mluví, i když drtivá většina z nich $(95 \%)$ ji používá pouze v ústní komunikaci. Podíl osob majících korsičtinu jako mateřský jazyk je přímo úměrný jejich věku. Řada mladých Korsičanů uvádí, že se naučili korsicky až v dospělosti, nebot' pochopili, že tento jazyk je důležitou součástí jejich identity a je jen velmi obtížné vznášet autonomistické požadavky bez znalosti tohoto jazyka. Řada mladých Korsičanů korsicky rozumí, ale jejich schopnost komunikovat v tomto jazyce je silně omezená. Až do druhé světové války ovládali korsičtinu téměř všichni Korsičané (Colonna, 2012, 42). V roce 1982 rozumělo korsicky $70 \%$ ostrovanů, tedy $96 \%$ populace korsického původu, a $86 \%$ rodilých Korsičanů pravidelně mluvilo korsicky. V současnosti se uvádí, že korsicky mluví 20 až $70 \%$ populace a počet mluvčích se liší v závislosti na zdroji a účelu zveřejňovaných informací. Nicméně je zjevné, že korsičtina je na ústupu, a podle UNESCO patří korsičtina mezi jazyky, kterým hrozí do konce 21. století zánik. Všechny osoby hovořící korsicky ovládají také francouzštinu. Francouzštinu užívají ve formální komunikaci, korsičtinu v komunikaci v rodině a s přáteli. Mluvčí jsou schopni oba jazyky střídat, a proto někteří jazykovědci hovoří o jazyce francorsu, v němž dochází k systematické alternaci francouzštiny a korsičtiny, nebo o korsické regionální francouzštině (français régional de Corse).

\section{Historie}

Prvními cizími osadníky na Korsice byli Řekové, kteří se zde rozhodli roku 565 před naším letopočtem založit nové město v místech, kde dnes leží obec Aléria a kde už v té době žili Korsičané. Římané se objevili na ostrově ve 3. století před naším letopočtem a zůstali zde až do 5. století našeho letopočtu. Podle svědectví filozofa Seneky (Arrighi, 2008: 507), který byl na Korsiku vyhnán roku 41 našeho letopočtu, nemluvili Korsičané latinsky. Jakým jazykem mluvili, však dodnes nevíme. Korsické obyvatelstvo postupně prrijalo latinu a křest’anství. Až do konce římské nadvlády tvořily Korsika a Sardinie jednu římskou provincii, což mělo pochopitelně vliv na jazyk obyvatel obou ostrovů. Existují slova, která se užívala pouze na Sardinii a na jihu Korsiky a nikde jinde na území Římské říše. Korsičané mluvili latinsky dříve než Galové a díky své izolovanosti zůstala korsičtina bližší latině než italština a další jazyky užívané na území Itálie.

Od 5. století našeho letopočtu podnikali útoky na Korsiku Vandalové, Ostrogóti, Saracéni ze Španělska i severní Afriky a Lombardové. Následně se Korsika stala společně s celou severní Itálií součástí říše Karla Velikého. Jazyk Franků v této době ovlivnil jazyk Korsičanů a obyvatel severní Itálie, avšak neměl vliv na jazyk obyvatel Sardinie. Následující dvě století byla Korsika pod papežskou správou, a to až do roku 1077, kdy papež Řehoř VII. předal správu Korsiky Pisánské republice, která používala jako úřední jazyk středověkou toskánštinu. V této době se korsičtina oddělila od latiny a stala se samostatným románským jazykem. Začala se také 
postupně od severu $\mathrm{k}$ jihu sbližovat s toskánštinou, a to nejen v oblasti lexika, ale i fonetiky, morfologie a syntaxe. Již v době, kdy byla Korsiky pod správou Pisánské republiky, založila Janovská republika na Korsice v roce 1195 kolonii Bonifacio. V roce 1284 porazila Janovská republika v námořní bitvě u ostrova Meloria Pisánskou republiku a převzala od ní správu Korsiky a Sardinie. Sardinii museli Janované záhy přenechat Aragonskému království, ale Korsiku si ponechali až do roku 1768. V písemné komunikaci používali Janované toskánštinu, avšak obyvatelé ostrova mluvili korsicky. V té době si korsičtina vypůjčila řadu lexikálních jednotek $\mathrm{z}$ janovštiny a zejména $\mathrm{z}$ toskánštiny. $\mathrm{Z}$ janovštiny převzala korsičtina pouze asi sto slov, což je vzhledem k pěti stoletím nadvlády Janovanů nad Korsikou málo, ale je to způsobeno tím, že Janované upřednostňovali v písemné komunikaci toskánštinu před svým jazykem. Důsledkem vlivu toskánštiny bylo to, že došlo k ukončení jazykové a kulturní jednoty se sardinštinou. Janovsky se mluvilo pouze v kolonii Bonifacio, kam přišli ve dvou vlnách osadníci z východní Ligurie, jejichž potomci si uchovali tento jazyk. Osoby, které neovládaly korsičtinu, zejména Janované, Toskánci a Francouzi, považovaly tento jazyk za „zkaženou italštinu“, která je výsledkem vlivů řečtiny, toskánštiny, sicilštiny, sardinštiny a janovštiny. Ostatně i dnes si řada lidí myslí, že korsičtina je nářečím italštiny.

Korsičané se pokoušeli opakovaně zbavit nadvlády Janovanů. V roce 1755 vyhlásil korsický generál Pasquale de Paoli nezávislost ostrova s vlastní ústavou, vytvořil korsický systém státní správy, soudnictví a založil univerzitu. Ústava byla napsána v italštině (toskánštině) a v tomto jazyce se vyučovalo i na univerzitě. Paoli mluvil korsicky, francouzsky a anglicky, ale v písemné komunikaci používal toskánštinu (Thiers, 1989: 26). Francouzský král Ludvík XV. odmítl uznat samostatnost ostrova a poslal na Korsiku v roce 1768 svou armádu a ostrov se stal francouzským územím a následně v roce 1790 francouzským departementem. V roce 1769, kdy se Napoleon Bonaparte narodil, byla Korsika násilím přičleněna k Francii. Jeho otec bojoval v Paoliho armádě a po Paoliho porážce se přidal k Francouzům. Ve věku devíti let byl Napoleon, který mluvil pouze korsicky, poslán do Francie, aby zde získal vojenské vzdělání. V monarchistickém prostředí byl považován za cizince a byl terčem posměchu svých spolužáků, což vedlo k tomu, že se z něho stal republikán, nebot' se domníval, že revoluce by mohla navrátit jeho Korsice samostatnost, a korsický patriot. Naučil se sice francouzsky, ale až do smrti mluvil s korsickým přízvukem a francouzštinu nikdy dokonale neovládal. V roce 1793 se vylodil ve městě Ajaccio s republikánskou armádou, aby ukončil povstání Paoliho stoupenců. Jakmile však viděl odpor Korsičanů, odjel i s rodinou do Francie. Když se stal v roce 1799 prvním konzulem, zahájil proces opětovného začlenění Korsiky do Francie. Stejně tak jako za Velké francouzské revoluce byla i za Napoleonovy vlády jednota země založena na jednotě jazykové. Všechny jazyky užívané ve státě, kromě francouzštiny, byly považovány za nářečí a měly být vymýceny. Stejný osud měl postihnout i korsičtinu. Nicméně Korsika je ostrov a uplatňování této politiky zde bylo mnohem obtížnější než v kontinentální Francii. Lidé mluvili stále korsicky a až do roku 1830 se v úředních dokumentech používala většinou toskánština. Za druhého císařství (1848-1870) se používala na Korsice italština, korsičtina a francouzština, a proto musel Napoleon III. v roce 1854 vydat nařízení, aby byly veškeré úřední dokumenty vyhotovovány ve francouzštině. Zakázána byla dokonce i italská opera. 
Lidé však francouzštinu př́liš neovládali, nebot' dříve se v písemné komunikaci používala toskánština, což je také jeden z důvodů, proč se v této době objevují první písemnosti v korsičtině. V osmdesátých letech 19. století přijal Jules Ferry řadu opatření, která měla oslabit pozici regionálních jazyků ve Francii. Byla zavedena bezplatná a povinná školní docházka, která se měla stát důležitým nástrojem pro rozšíření používání francouzského jazyka. Za třetí republiky (1870-1940) se francouzština stala jediným jazykem užívaným na Korsice ve školách, na soudech a na úřadech (Ottavi, 2014: 66). Italština přestala být jazykem kultury a korsičtina se užívala pouze v neformální ústní komunikaci.

Již od napoleonských válek docházelo na Korsice k projevům nespokojenosti místní populace, které francouzský stát potlačoval, což vedlo k zesílení snah o autonomii ostrova. V roce 1972 ještě francouzské ministerstvo školství odmítlo návrh na výuku korsičtiny jako nepovinného předmětu se zdůvodněním, že tento jazyk není jednotný a není kodifikovaný. O dva roky později přiznala francouzská vláda korsičtině tím, že ji začlenila do Zákona č. 51-46 z 11. ledna 1951 (Loi no 51-46 du 11 janvier 1951), statut regionálního jazyka, který již od roku 1951 měly bretonština, baskičtina, katalánština a okcitánština, a korsičtina začala být vyučována jako volitelný předmět na místních školách. V roce 1982 získala Korsika statut územního společenství, ale místní nacionalisté kladli další požadavky směřující $\mathrm{k}$ ještě větší autonomii ostrova. V roce 1991 schválil francouzský parlament Zákon č. 91-428 ze dne 13. května 1991 o statutu Korsického územního společenství (Loi no 91-428 du 13 mai 1991 portant statut de la collectivité territoriale de Corse). Tento zákon poskytl Korsickému shromáždění, jehož členové jsou voleni ve všeobecném hlasování, řadu pravomocí v oblasti ekonomiky, místního rozvoje a vzdělávání. Tyto pravomoci byly $\mathrm{v}$ rámci tradičního francouzského centralismu poměrně velké, i když místní zákonodárné shromáždění nemohlo přijímat své vlastní zákony. Pokud jde o korsický jazyk, tak se pouze v článku 44 hovořilo o ochraně a šíření korsického jazyka a kultury a v článku 52 o tom, že Korsické shromáždění přijme plán rozvoje výuky korsického jazyka a kultury, a to zejména na školách, přičemž podrobnosti tohoto plánu budou uvedeny $\mathrm{v}$ dohodě uzavřené mezi územním společenstvím a francouzským státem. I přesto pouze několik dnů po schválení tohoto zákona zrušila francouzská Ústavní rada (Conseil constitutionnel), obdoba našeho Ústavního soudu, článek 1 tohoto zákona $\mathrm{z}$ důvodu jeho neústavnosti, nebot' v něm byl použit termín „korsický lid“ (peuple corse). Proti tomu se postavili korsičtí politici a zejména Fronta národního osvobození Korsiky (Front de libération nationale de la Corse, FLNC), nebot' bez uznání „korsického lidu“ postrádá statut Korsiky smysl. V roce 1992 schválilo Korsické shromáždění Návrh na uznání korsického jazyka za úřední jazyk (Motion sur l'officialisation de la langue corse), který sice francouzský stát neschválil, ale který lépe vystihoval požadavky korsických představitelů $\mathrm{v}$ jazykové oblasti.

V roce 2000 rozš́iŕilo Korsické shromáždění svým rozhodnutím autonomii Korsiky a umožnilo „upravovat“ francouzské zákony pod kontrolou francouzského parlamentu. O rok později přijalo francouzské Národní shromáždění Zákon č. 200292 ze dne 22. ledna 2002 o Korsice (Loi no 2002-92 du 22 janvier 2002 relative à la Corse), který jako obvykle opět zcela neuspokojil místní nacionalisty. Senát navíc znění tohoto zákona pozměnil. Změny se týkaly pravomocí Korsického shromáždění a také výuky korsičtiny. V původním návrhu bylo v článku 7 uvedeno, že korsický 
jazyk je předmět běžně vyučovaný na korsických mateřských a základních školách, kdežto v Senátem schválené verzi se můžeme dočíst, že korsický jazyk je předmět, jehož výuka je běžně nabízena na korsických školách, čímž bylo zdůrazněno, že korsičtina je nepovinným volitelným předmětem. Ústavní rada navíc rozhodla, že francouzský parlament nemůže převést na Korsické shromáždění pravomoc přijímat zákony, ale pouze nařízení. V referendu konaném v roce 2003 odmítla těsná většina Korsičanů nový úřední statut jejich ostrova.

V roce 2013 schválilo Korsické shromáždění návrhy, aby se korsičtina stala druhým úředním jazykem ostrova a aby byla revizalizována (Propositions pour un statut de co-officialité et la revitalisation de la langue corse). Francie však tento předpis neuznala. Korsické shromáždění požaduje, aby se korsičtina používala ve všech oblastech veřejného, hospodářského a společenského života, zejména ve vzdělávání, ve veřejných službách a v médiích. Návrhy počítají s rozsáhlým školením zaměřeným zejména na osoby pracující ve veřejných službách, které má napomoci, aby bylo možné standardizovat uživání korsičtiny ve všech oblastech a zajistit její rovnocenné postavení s francouzštinou. V článku 3 se uvádí, že francouzština a korsičtina jsou úředními jazyky Korsiky na území spravovaném Korsickým územním společenstvím a úřady musejí přijmout opatření, aby bylo zaručeno používání korsičtiny jako jazyka veřejných služeb a pracovního jazyka. Podle článku 4 mají občané právo komunikovat $\mathrm{s}$ úřady ústně i písemně v korsičtině nebo ve francouzštině, aniž by byli jakkoliv $\mathrm{z}$ důvodu výběru jednoho $\mathrm{z}$ úředních jazyků diskriminováni. Článek 9 je věnován bilingvnímu vzdělávání. Bilingvní má být celý korsický vzdělávací systém od mateřských až po vysoké školy. Cílem vzdělávání je zajistit, aby všichni žáci na Korsice byli bilingvní a po ukončení povinné školní docházky ovládali francouzštinu i korsičtinu aspoň na úrovni B2. Korsičtinu na této úrovni musejí ovládat podle článku 16 také všichni státní zaměstnanci. Tyto návrhy však nemají platnost zákona a Korsické shromáždění nemá pravomoci na to, aby si vynutilo jejich aplikaci v praxi. Proti těmto opatřením se staví nejen francouzský stát a jeho vláda, ale i obyvatelé Korsiky, kteří nejsou korsického původu a kteří dnes tvoří téměř polovinu místní populace. Paradoxní je to, že proti těmto návrhům ostře vystupoval zejména tehdejší francouzský ministr vnitra a pozdější premiér Manuel Valls, který pochází z Katalánska, kde se katalánština stala jazykem katalánské státní správy a vyučovacím jazykem na školách a stále více se užívá na úkor španělštiny ve sdělovacích prostředcích a každodenním životě, a který získal francouzské občanství teprve ve věku 20 let. Situace je stále napjatá, nebot' od roku 2015 je Korsické shromáždění ovládáno nacionalisty. Jeho předseda Jean-Guy Talamoni ze separatistické strany Corsica Libera opakovaně prohlásil, že Korsika není francouzská a společně s dalšími př́iznivci větší autonomie Korsiky požaduje zrušení dvou francouzských departementů a jejich nahrazení jediným územním společenstvím.

\section{Současné postavení korsičtiny}

V současnosti nemá korsičtina stále žádný skutečný právní statut, a proto téměř veškerá formální komunikace na ostrově probíhá stále ve francouzštině. Francouzština je rovněž nejčastěji užívaným jazykem v Korsickém shromáždění, i 
když někteří nacionalističtí zastupitelé užívají někdy ve svých vystoupení korsičtinu. Ústní komunikace $\mathrm{v}$ korsičtině probíhá $\mathrm{i}$ na obecních a městských úřadech, ale veškeré písemnosti jsou vyhotovovány pouze ve francouzštině. Francouzština je jediným jazykem užívaným v místním soudnictví a veškeré dokumenty v korsičtině jsou neplatné a soudy je nepřijímají. Výhradně ve francouzštině pracují rovněž veškeré státní a krajské orgány působící na Korsice a znalost korsičtiny u úředníků není vyžadována.

$\mathrm{S}$ výukou korsičtiny začalo počátkem sedmdesátých let, tedy v době, kdy došlo k vytvoření pravopisné normy tohoto jazyka, neziskové sdružení Scola corsa a následně se objevila korsičtina i na státních školách (Di Meglio, 2009: 86). První studenti skládali maturitu z korsičtiny v roce 1975. V roce 1983 se Korsické shromáždění vyslovilo pro bilingvní vzdělávání od mateřské až po vysoké školy. V článku 5 Návrhu na uznání korsického jazyka za úřední jazyk z roku 1992 se dočteme, že ve školním roce 1992/1993 se žáci na všech stupních korsických škol budou učit korsicky minimálně 3 hodiny týdně. Toto nařízení však nebylo uplatněno $\mathrm{v}$ praxi, nebot' tento návrh nemá žádnou právní platnost. Podle francouzského státu není možné, aby výuka korsičtiny byla povinná. Článek 52 Zákona č. 91-428 ze dne 13. května 1991 o statutu Korsického územního společenství nicméně umožňuje korsickým orgánům místní samosprávy přijímat nařízení týkající se výuky korsičtiny. Na základních školách se účastnilo ve školním roce 2016/2017 výuky korsičtiny 25521 žáků, což představuje 98 \% všech žáků zapsaných na korsických základních školách. 11807 žáků se učilo korsicky méně než tři hodiny týdně (v průměru hodinu a půl), 4888 mělo 3 až 6 hodin korsičtiny a 8801 žáků se zúčastnilo kromě tř́ hodin korsičtiny také výuky některých jiných předmětů v korsičtině. Možnost učit se korsicky nemělo pouze 521 žáků a žádný žák neodmítl možnost navštěvovat výuku korsičtiny, pokud mu byla nabídnuta. Na středních školách studovalo korsičtinu 9413 studentů, tedy 44,15 \% všech korsických středoškoláků, z toho 7468 studentů, čili $59,7 \%$, na prvním stupni středních škol (collège), 1210 , tedy 22,20\%, na druhém stupni středních škol, (lycée) a 735, čili 26,92 \%, na středních odborných školách (lycée professionnel). Jako druhý živý jazyk si zvolilo korsičtinu 731 studentů, jako třetí živý jazyk, což je možné pouze ve třídách s humanitním zaměřením, 385 studentů a 8297 studentů si vybralo korsičtinu jako volitelný předmět s dotací 3 hodiny týdně. Dvojjazyčné výuky, tedy výuky, kde je část předmětů (někdy až $50 \%$ ) vyučována v korsičtině a část ve francouzštině, se zúčastnilo 9010 žáků $(34,67 \%)$ korsických základních škol a 2094 studentů (9,82 \%) středních škol. Pokud jde o vysoké školy, tak již v roce 1957 bylo na Filozofické fakultě v Aix-en-Provence založeno Centrum korsických studií (Centre d'études corses). V roce 1981 byla po více než dvou stech letech znovu otevřena Korsická univerzita (Université de Corse), založená už v roce 1765 a nesoucí nyní jméno Pasqueleho Paoliho, kterou prošli v podstatě všichni učitelé korsického jazyka a kultury. Výuka korsičtiny na základních a středních školách se za poslední dobu velmi rozšírila. Účastní se jí stále více žáků, avšak žáci, jejich rodiče a bohužel často i samotní učitelé ji nepovažují za důležitou a korsičtina patří mezi předměty, jimž věnují místní žáci a studenti nejmenší pozornost.

Celkově je možné říci, že korsičtina nezaujímá př́iliš významné místo ve zdejším společenském životě. Řada periodik se sice věnuje životu na Korsice, ale jen velmi málo z nich je vydáváno pouze v korsičtině, nebot’ řada Korsičanů má s četbou 
v tomto jazyce problémy. Většina periodik vychází ve francouzštině, ale je možné v nich nalézt i články v korsičtině. Pouze v korsičtině vycházejí periodika prezentující názory místních nacionalistů a separatistů. Korsičtina se objevuje také v televizi a ještě více v rozhlase. Dvojjazyčné jsou i směrové tabule na silnicích, kdežto jazykem reklamy je jednoznačně francouzština.

\section{Závěr}

Pokud srovnáme postavení korsičtiny s postavením jiných regionálních jazyků v evropské a zejména v zámořské části Francie, tak vidíme, že nový statut ostrova postavení korsičtiny př́liš nezlepšil. Pro Korsiku, která nebyla nikdy ve své historii samostatná, a tudíž zde korsičtina nemohla být nikdy uznaným úředním či národním jazykem, je typická diglosie. Osoby ovládající korsičtinu ji používají takřka výhradně k neformální ústní komunikaci, zatímco ve formální ústní komunikaci a v komunikaci písemné se uchylují k francouzštině. Korsičtina, která nebyla nikdy nejdůležitější součástí identity Korsičanů, nebot' ta je dána především územní a historickou jednotou tohoto území, je na ústupu, ačkoliv ji paradoxně studuje na korsických školách stále více žáků a studentů a místní politici se všemožně snaží o zlepšení jejího statutu. Korsičtina je zjevně na cestě od hojně používaného regionálního jazyka k jazyku kulturního dědictví. Jazyk je sice popisován místními jazykovědci, mladí Korsičané se s ním seznamují na školách, ale používají ho stále méně. Je paradoxní, že místní politici chtějí, aby se korsičtina používala $\mathrm{v}$ úřední komunikaci, ale tento jazyk je stále více nahrazován francouzštinou v neformální komunikaci, v níž se dř́ve běžně používal. Zdá se, že jazyková otázka rozhodně nepatří mezi největší priority místních nacionalistů, což je škoda, nebot' demografický vývoj, pro který je typické stěhování Francouzů z kontinentu na ostrov a snižování podílu osob korsického původu, není pro budoucnost korsičtiny př́znivý a mohly by se tak naplnit obavy UNESCO, které zařadilo korsičtinu na seznam jazyků, jimž hrozí do konce 21. století zánik.

\section{Bibliographic references}

ARRIGHI, J.M. 2002. Histoire de la langue corse. Paris: Gisserot, ISBN 2-87747663-4

ARRIGHI, J.M. 2008. Langue corse: situation et débats. Ethnologie française 38/3, pp. 507-516, ISSN 0046-2616

COLONNA, R. 2011. Les langues minoritaires au sein de l'Union europeenne: quelle politique pour quel avenir. In: HERRERAS, J. C. (Éd.) L'Europe des 27 et ses langues. Valenciennes: Presses universitaires de Valenciennes, pp. 99-116, ISBN 9782-36424-008-7

COLONNA, R. 2012. Langue corse ou l'histoire ambivalente. Lengas 71, pp. 41-50, ISSN 0153-0313

COMITI, J.M. 2005. La langue corse, entre chien et loup. Paris: Harmattan, ISBN 27475-9389-4

DALBERA, J.-P. 2003. Les îlots liguriens en France. In: CERQUIGLINI, B. (Éd.) Les langues de France. Paris: PUF, pp. 125-136, ISBN 978-2130532859

DI MEGLIO, A. 2003. L'avènement de l'enseignement du corse. In: FUSINA, J. (Éd.) Histoire de l'école en Corse. Ajaccio: Albiana, pp. 507-546, ISBN 978-2846980241

XLinguae, Volume 11 Issue 1XL, January 2018, ISSN 1337-8384, eISSN 2453-711X 
DI MEGLIO, A. 2009. La langue corse dans l'enseignement: donnees objectives et sens sociétal. Trema 31, pp. 85-94, ISSN 1167-315X

DI MEGLIO, A. 2014. Formation des professeurs des ecoles en Corse et defi des langues integrees: voies et problématiques. Trema 42, pp. 102-113, ISSN 1167-315X DUBET, F. 2004. L'ecole des chances. Qu'est-ce qu'une ecole juste? Paris: Seuil, ISBN 978-2020685795

FUSINA, J. 2003. Le corse. In: CERQUIGLINI, B. (Éd.) Les langues de France. Paris: PUF, pp. 95-106, ISBN 978-2130532859

OTTAVI, P. 2008. Le bilinguisme dans l'école de la République? Le cas de la Corse. Ajaccio: Albiana, ISBN 978-2846982764

OTTAVI, P. 2014. Ecole et sentiment identitaire en Corse, sous la $\mathrm{III}^{\mathrm{e}}$ Republique. Carrefours de l'éducation 38/2, pp. 65-79, ISSN 1262-3490

LECLERC, J.: France. Aménagement linguistique dans le monde [www dokument 30. 6. 2017], Available online: http://www.axl.cefan.ulaval.ca/europe/france.htm THIERS, J. 1989. Papiers d'identité(s). Livia: Albiana, ISBN 978-2905124098

Words: 4094

Characters: 27662 (15,37 standard pages)

doc. Mgr. Jaromír Kadlec, Dr.

Department of Romance Languages

Faculty of Arts

Palacký University Olomouc

Kř́žkovského 511/10

77147 Olomouc

Czech Republic

jaromir.kadlec@upol.cz 